\author{
Paulina Sztabińska \\ Department of Art History \\ University of Łódź \\ paulina.sztabinska@uni.lodz.pl
}

\title{
PERFORMANCE AND PARTICIPATORY ART
}

\begin{abstract}
The relationship between participatory art and performance is complex. On the one hand, their affinity is recognized, because in both cases we are dealing with emphasizing the role of action, but on the other, this action is understood differently. If the first aspect is taken into account, in museum or gallery press releases the manifestations of participatory art are referred to as "performances" - sometimes accompanied by an adjective. The aim of the article is to take a closer look at this issue.

The discussion begins by highlighting the fact that happenings (especially European) from the 1960s are more often considered as a reference point for participatory art than performance art. Claire Bishop points to the conscious socio-political criticism of the consumer society that appears in happenings. The author of the article argues that the structure of these activities may also be an argument. When discussing the rules of public participation in happenings and performance art, she cites Erika Fischer-Lichte's views that in the latter case a "feedback loop" should be created between the performer and the audience. Such a loop is not formed in the case of happenings and cannot be shaped in participatory art, where the artist is only one of the people participating in the action. The article examines examples of characteristic works based on the principle of participation: Rirkit Tiravanija, Tania Bruguera and Pawel Althamer. In none of them did the artist occupy a distinguished position, she/he did not affect the way the participants behaved, and she/he only created an opportunity for a community. In the first case, its formation was completely free, in the second - there were forms of pressure release from it, in the third - there was encouragement. Nowhere, however, did the artist define the rules of action, did not determine the stake, did not set goals. At the same time, while making the participants the creators of the course of the action, the question "What for?" remains important in participatory art, which lends it a political character.
\end{abstract}

Keywords: participatory art, happening, performance art, Nicolas Bourriaud, Claire Bishop, Erika Fisher-Lichte 
One might get the impression that participatory art stems from performance, or even that the boundaries between these types of contemporary art are becoming blurred. Meanwhile, when writing about relational aesthetics, ${ }^{1}$ Nicolas Bourriaud stresses that it rather originates from exhibitions of painting or sculpture, albeit considered broadly, taking into account the various types of activities that are related to them. Apart from the objects presented in the gallery space, the various social practices that take place in the gallery should be included. The French author refers here to the viewers' participation, the way it relates to the presented works, the ways of perception, the activities performed, consisting both in interaction with the presented objects and in mutual relations between members of the audience - grouping, dispersing, undertaking or not undertaking conversations or joint actions, etc. Bourriaud writes: "Art (practices stemming from painting and sculpture which come across in the form of an exhibition) turns out to be particularly suitable when it comes to expressing this hands- on civilization, because it tightens the space of relations, unlike TV and literature which refer each individual person to his or her space of private consumption, and also unlike theatre and cinema which bring small groups together before specific, unmistakable images. Actually, there is no live comment made about what is seen (the discussion time is put off until after the show). ${ }^{2}$ The French critic therefore believes that art has always been relational in some respects and on various levels. What is most important from the perspective of relativity is the search for various types of proximity between people. In this respect, the concept of relational aesthetics is a reference to the critique of the public performance by Guy Debord. ${ }^{3}$

The issue of proximity is understood differently in individual concepts of participatory art. For example, Grant Kester, while emphasizing the role of dialogue, not only does not exclude but even stresses differences of opinion, disputes or controversies. Referring to Mikhail Bakhtin's theory of dialogue, he takes into account the presentation of many different views, which are always a response to earlier statements and foster the emergence of new positions. It

1 My understanding of 'participatory art' includes its different artistic varieties and theoretical concepts, in particular the 'relational aesthetics' of Nicolas Bourriaud, the 'participatory art' of Claire Bishop and the 'dialogical aesthetics' of Grant Kester. The term participatory art shall be taken as a priority considering the decision made in Encyclopdia of Aesthetics, editorin-Chief Michael Kelly, Oxford University Press, 2014 (http://arts.berkeley.edu/wp-content/ uploads/2015/03/Participatory_Art-Finkelpearl-Encyclopedia_Aesthetics.pdf).

2 N. Bourriaud, Relational Aesthetics, transl. Simon Pleasance and Fronza Woods with M. Copeland, Les presses du réel, Dijon, 2002, pp. 15-16. Originally published in French by same publisher in 1998 as Esthétique relationnelle.

3 Cf. G. Debord, The Society of the Spectacle, transl. D. Nicholson-Smith, Zone Books, New York 1994. 
assumes that statements can, and should, be different or contradictory because they express individual points of view. However, what unites the action of dialogue art is a subject important from the social point of view and a common place where the participants communicate. ${ }^{4}$ Claire Bishop places significantly more emphasis on antagonistic elements. In her well-known article published in 2004 in the magazine "October", she criticized Bourriaud's notion that in the case of participation the sphere of human interaction and its social context is more important than independent and symbolic private spaces, in order to indicate that fundamental contemporary conflicts are not addressed in this way. Nor does dialogue have to become automatically democratic and good, helping to solve problems. However, what does the word 'democracy' mean in this context? Bishop refers to the views expressed in Ernesto Laclau and Chantal Mouffe's book Hegemony and Socialist Strategy, where antagonism is not understood as a pessimistic acceptance of political impasse. It is associated with "decentralization", which does not imply a lack of autonomous subjectivity but means political will and self-determination. This lends the issue of artistic participation in Bishop's writings a strong political dimension. ${ }^{5}$

Taking these concepts into account, one could conclude that the revival of interest in performance in the 1990s was an expression of a more general tendency to emphasize the role of functional elements in art, while limiting the role of th"cal references, it is rather by comparing them with certain types of activities of the Avant-Garde of the first half of the twentieth century, or with the happening tradition of the 1960s. Bourriaud attempts to prove that relational art is an original phenomenon. Kester refers to selected achievements of the erstwhile Avant-Garde. In her book in Artificial Hell: Participatory Art and the Politics of Spectatorship, Bishop refers to examples of European happenings from the 1960s, both in Western and Central Europe. I believe that explaining these theoretical decisions may bring us to consider ways of activating participants in the references they consider or ignore.

Claire Bishop is the one to take the greatest account of the references of participatory art to the twentieth century artistic tradition. In addition to the theoretical contexts, ${ }^{6}$ she also considers participation issues in proto-happening

4 Cf. G. Kester, Converation Pieces: Community and Communication in Modern Art, University of California Press, Berkeley 2004.

5 Cf. C. Bishop, Antagonism and Relational Aesthetics, in: Theory in Contemporary Art since 1985, ed. Z. Kocur and Simon Leung, Wiley-Blackwell, Malden-Oxford-Chichester 2012, pp. $168-180$.

6 Historical theoretical contexts of participatory art were presented by the author in her anthology of texts titled Participation. Documents of Contemporary Art, Whitechapel and The MIT Press, London - Cambridge, Mass. 2006. 
(Futurist, Dadaist and Constructivist) and happening activities. She attaches particular importance to selected actions organized in the 1960s and 1970s. One of the reasons for this is to emphasize the political aspect, which is important for the author. Bishop believes that this issue is "the strongest dividing line between European and North American Happenings". She wrote, "As Günter Berghaus argues the European work (Lebel, Wolf Vostell, Robert Filliou, the Viennese Actionists) contained a conscious socio-political critique of affluent consumer society; the North Americans, by contrast, 'regarded their activity as an apolitical means of changing people's attitudes toward life. In some cases, this may have implied a socio-critical attitude. But more often it was restricted to altering the process of perception"'. ${ }^{7}$ The difference, therefore, related to both the general attitude and the consequences in terms of focusing attention on particular components of the planned action and indicating its objectives and consequences. American happenings were about bringing art closer to life in general, about actions that were not a recreation or presentation of reality (as in the theatre), but about behaviors such as those in everyday situations. That is why actors, who were not able to give up the role-playing mindset and who were asking: "who should I be?" were not invited. When they heard the answer that they were supposed to be themselves in the happenings, they were simply helpless. American artists employed the help of their colleagues (painters, sculptors) to ask them to animate the action. As a result, American happenings generally referred to the conflict, as Berghaus puts it, "between our real self and its alienated state. Through the performance the audience was encouraged to experience the authenticity of their existence in opposition to "life unlived" ". ${ }^{8}$ In the case of European happenings, a similar situation was related to specific social and political issues and treated not as a symptom of the human condition, but as a result of conflicts taking place here and now.

Due to this difference, the North American happening artists focused on developing action structures that would prevent participants from passivity typical of traditional art audiences. Allan Kaprow consistently applied this approach in many of his early activities. He rejected the possibility of exerting pressure on the participants in order to activate them, but assumed that the experience of authenticity associated with personal participation in the event could be achieved by developing a score for the happening that would predict what each person should do. These scores were discussed with all the people before the action. Thus Kaprow noted, Tadeusz Pawłowski writes, "that participation in the happening requires the audience to fulfill the same conditions as

7 C. Bishop, Artificial Hell Participatory Art and the Politics of Spectatorship, Verso, London, Ney York 2012, pp. 94-95.

8 Quoted in ibid, p. 95. 
the artist has decided to - it requires liberating oneself from convention, renouncing one's life privileges, and exposing oneself to the risk associated with it. 'Education' of the audience, its awakening and transformation into active participants sometimes consist in evoking a sense of superfluity and inadaptability among the viewers, who passively behave in accordance with the theatrical tradition". ${ }^{9}$

Pawłowski emphasizes that among the methods American happeners use, the most important ones are issues related to influencing the process of perception in the audience. However, this process of perception is not linked to social or political factors, belonging to a particular class or social group, etc. It can therefore be said that the aim was to take into account the formal conditions associated with perception..$^{10}$ An example is the happening by Claes Oldenburg Gayety (Chicago 1963), based on the principle of designating public places and provoking various reactions. The title referred to the famous burlesque theatre in Chicago, but the happening did not have a paratheatrical character and was largely focused on the relations between members of the audience. Oldenburg, dressed in a white apron and standing on a plinth, directed the audience to certain parts of the room. First, the participants sat on chairs facing the podium. Another group pointed at places with their backs facing him. This provoked their protests, as it was thought that a performance would soon start, which they would not be able to see with the faces of the first group of spectators in front of them. The other recipients were placed on the elevator in a part of the room where there were some chairs, but many people had to stand. On the walls of the room there were also two mirrors, which made it possible to follow the action, but indirectly, as a reflection. The participation of the audience in this case was therefore based on different points of view and ways of perceiving. This triggered activity that involved standing up, rotating and tilting.

Apart from organizing happenings, in which situations were created that made the participants aware of certain scopes of activities and related possibilities, or inability to perform some of them, American artists considered the issue of treating the audience as "ready-made", encouraging them to perform usually simple, everyday activities, etc. Sometimes the viewers were asked to handle certain objects (e.g. broomstick), at other times a kind of pressure was applied. Sometimes it was expected that unpredictable actions of the participants of the happening would introduce an element of chance, so desired by creators. In all such situations, there was a kind of participatory experiment. The artists, even

9 T. Pawłowski, Happening, Wydawnictwa Artystyczne i Filmowe, Warsaw 1988, p. 72.

10 Issues of linking happenings to current political problems arose in the United States a little later, and especially in paratheatrical activities. The Living Theatre was then on "self-imposed exile from New York" and touring Europe with its performances. (cf. B. Bishop, Artificial Hells..., op. cit., p. 96). 
if they were unable to predict how the audience would behave, had a clear idea of what kind of activities they wanted. Contact with the audience was all the easier because the audience consisted mainly of people who regularly attended artistic exhibitions, especially avant-garde ones.

As I have mentioned, when discussing the history of the concept of artistic participation and its manifestations in the twentieth century in her book Artificial Hells, Claire Bishop almost completely ignores American achievements. Taking into account European happenings of the 1960s, she pays particular attention to the work of Jean-Jacqes Lebel. Art criticism in the 1960s and 1970s (also in Poland) described his actions as excessively theatrical. Therefore, it is worth considering why one of the most important theorists of participatory art pays attention to them.

Bishop emphasizes that while the two "foundations" of the American happening were John Cage and Jackson Pollock, Lebel was rather inspired by the achievements of Dadaists, Surrealists, as well as the ideas of Antonin Artaud. She also quotes Lebel's statement, in which he refers to both American and European happenings, but which is, above all, characterized by his own position. There he emphasizes the need to "give back to artistic activity what has been torn away from it: the intensification of feeling, the play of instinct, a sense of festivity, social agitation". ${ }^{11}$ So, contrary to the role of conceptual assumptions, important for American artists, what counts here are emotions and instincts, which are to liberate the participation in the happening. Appealing to feelings and drives, Lebel wanted the participants to spontaneously join in, first of all mentally, and sometimes only physically. He did not use coercion, nor did he assign seats or roles. As Bishop writes, Lebel drew on painting (of an expressive nature) and, above all, on jazz, which played the role of "an improvisational structuring device for collaborative events with a changing entourage of artist colleagues and colorful hangers-on". ${ }^{12}$ Moreover, in contrast to American artists, for whom it was important to develop the "score" of the happening (even if there were deviations from it during the performance), here "events were not scored, but unfolded in an ad hoc fashion around a cluster of scenes or episodes, arrived at through group discussion". ${ }^{13}$ The event, which included a series of actions, was shaped to the rhythm of jazz music performed by several instrumentalists, and the improvised nature of the works was a direct analogy to the loose structure of the activities. The audience was not generally invited or urged to physically participate in what happened during the happenings. The participation, according to Lebel's assumptions, was psychological and

11 C. Bishop, Artificial Hells ..., op. cit. p. 94.

12 Ibid.

13 Ibid. 
based, as he said in reference to the action Pour conjurer l'esprit de catastrophe (Exorcising the spirit of disaster) of 1962, on "reactivity", albeit understood dialectically. Therefore, it was about "reversing the very terms of anxiety, a bit like a voodoo rite". ${ }^{14}$ Instead of presenting directly what people were afraid of at the time and causing the current and intensified horror, a game was played with its elements. Lebel said that as his starting point he took that which constituted the everyday life of the members of the consumer society and gave it back in his happening "like a bag with all its crap: nuclear technology, war (1962, it was the end of the Algerian war), exploitation, misery, racism, pop fans, advertising, porn, cars, sport, the serious threat of a generalized nuclear conflict (the Cuban Missile Crisis and Soviet missiles)". ${ }^{15}$

Bishop writes that there was a specific understanding of the issue of viewer participation in Lebel's happenings. They stressed "the artist's role in society to be one of moral transgressors, giving image and voice to what is conventionally repressed". ${ }^{16}$ However, she/he is neither a leader nor educator, but a transmitter of collective hopes and desires. She/he does not impose her/his interpretation of the facts, does not indicate the possibility of changes, does not instruct and does not agitate. The anticipated modifications in the feelings and attitudes of the participants of the events were to occur, as Lebel pointed out, through the emanation of a collective mind. Therefore, he did not distinguish between the performers and the audience. He emphasized this fact in a 1965 text entitled A Point of View on Happenings from Paris. He stated that all the current regimes, both in the so-called democratic states and in the so-called socialist states, were based on various taboos and repressions. The happenings he proposed were not supposed to be based solely on overcoming those taboos, giving people something to look at, but on "giving them something to do, something to participate in and create with. We are giving them a language for their hallucinations, desires and myths" ${ }^{17}$ The reactions of the participants were not limited to the passive reception, and what was seen was supposed to be the material for the psychological activity occurring also after the end of the reception, returning in various situations and as a result changing lives. In this way, as Lebel wrote, "organized repression, great invisible brainwashing, computerized patterns of culture" were to be disrupted and disassembled. ${ }^{18}$ There was supposed to have been a cathartic effect, but not only in the individual dimension. Besides, this form of catharsis was to be transformed into action.

14 Quoted in ibid., p. 96.

15 Quote by ibid.

16 Ibid, p. 97.

17 J.-J. Lebel, A Point of View on Happenings from Paris. Paris, September 1965, cited based on the reprint in: Jean-Jacques Lebel. Return from exile. Paintings, Drawings, Collages. 1954-1988, exhibition catalogue Galerie 1900-2000, Paris 1988, p. 69.

18 Ibid. 
Considering the work of the French happenner from the point of view of its links with the participatory art thirty years later, Bishop wrote: "Lebel's Happenings [...] were less about 'giving people things to do' than entering into a space of collective transformation where categories of individual and social, conscious and unconscious, active and passive, would purportedly disintegrate in a défoulement or unleashing of pent-up tensions". ${ }^{19}$ Unlike other happenings, especially American, the role of the artist was not clearly dominant. The artist did not suggest to her/his audience what to do and did not assume that as a result a certain kind of internal transformation would take place. Neither did she/he create a situation in which the viewers, upon becoming active, were to perform something unpredictable, accidental, an expression of temporal fear, pain or joy. In such situations, recipients would be treated to some extent as participants in psychological or sociological experiments, rather than as independent, autonomous, free beings deciding what they wanted to do and what they did not want to do. During Lebel's happenings, the recipients retained their physical and mental autonomy, and entering the "space of collective transformation" was their own decision. "Lebel, by contrast," Bishop writes "created quasi- therapeutic collective rites where societal taboos and inhibitions could be expressed and challenged". ${ }^{20}$ According to the author, this was preceded by an atmosphere of "politicized street theatre" during the Paris events in May 1968. That is how Lebel himself saw this issue. As he wrote, "The May uprising was theatrical in that it was a gigantic fiesta, a revelatory and sensuous explosion outside the 'normal' pattern of politics [...] The results of this individual as well as social change were immediate: human relations were freer and much more open; taboos, self- censorship, and authoritarian hang-ups disappeared; roles were permutated; new social combinations were tried out". ${ }^{21}$ The traits indicated in this statement later became the starting point for certain forms of participatory art. Of course, they were implemented on a narrower scale than during the Paris events, but provoking a situation in which human relations would become more open, based on freedom, free from self-censorship and authoritarian forms of behavior, based on changes in roles and new social combinations, became the target of many situations provoked by artists at exhibitions and during organized artistic actions.

The relation between happening and performance art is today usually presented on the basis of the recognition of the superiority of the latter concept. It is believed that "performance" is a broader concept, which includes, among other

19 C. Bishop, Artificial Hells..., op. cit., p. 101.

20 Ibid, p. 102.

21 Ibid. 
things, the notion of "happening". ${ }^{22}$. This has not always been the case, however, and the issue of the relationship between happenings and performance art has been discussed by artists, art theorists and critics. An example is the conference that accompanied the Third International Symposium of Performances in Lyon (1981), organized by Orlan and Hubert Besacier. One of the recurring issues was the attitude of performing activities towards happening actions. The differences between them were most often recognized, emphasizing the main role of the subject in the performances. Birgit Pelzer explixitly defined performance as "art of the Ego". ${ }^{23}$ Similarly, Tadeusz Pawłowski emphasized that while in the case of happening the attitude of "extrovert-objectivist" prevails, the performance involved an "introvert-subjectivist" approach. In many happenings, he claimed, the function of objects is equated with that which is attributed to human participants. If viewers are stimulated to an autonomous, creative participation, the latter usually involves activities associated with objects that obstruct the path, that are shifted, lifted, etc. That is why the objectives of these activities, formulated by their authors, were meant to liberate the activity of the participants, thus leading to a change in the surrounding world. Performers usually do not want to spur groups of people into action. Instead, they stress "the special role of the human individual and its uniqueness". ${ }^{24}$ Therefore, as Pawłowski noted, the role of used objects in performances is limited and no attempt is made to transform the audience into active participants.

I do not want to consider at this point how far these views are of a historical nature, associated with a certain moment in the development of performance art and the scope of examples to which the authors of the presented theses could refer. What is important, however, is whether the above-mentioned emphasis on the role of Ego, or on the introverted-subjective attitude, is related to the behavior of the viewers of the performance? Does subjectivism lead to a kind of solipsism, or does it create a basis for a different way of defining interpersonal relations than in the case of happening?

I am adopting Erika Fischer-Lichte's reflections on the aesthetics of performativity as a point of reference. In the first chapter of her book, the author cites Marina Abramović's Lips of Thomas and based on that she poses a question about the relationship between the artist and the audience. This

22 An example of such a position is the entry "Performance art" in the dictionary of modern art compiled by Amy Dempsey. The author also includes Actions, Live Art, Direct Art and Body Art in the scope of the title term (cf. An Encyclopaedic Guide to Modern Art Styles, Schools and Movements, Thames \& Hudson, London 2002, p. 223).

23 B. Pelzer, "Questions Relating to Performance", in: 1979-1983. Five Years Performance-Art in Lyon, ed. H. Besacier, M. Verdier, Comportement Environment Performance, Lyon 1984, p. 154.

24 T. Pawłowski, Introvert-Subjectivist Performance Versus Extrovert-Objectivist Happening, in: Ibid, p. 167. 
performance (sometimes defined as Body Art) has a clearly introverted and subjective character and emphasizes the role of the artist's self. The items used are kept to a minimum. As a result, there is no work autonomous of the presented action. The audience in Innsbruck, where the action was performed in 1975, focused on the activities performed by Abramović on her own body. At the same time, the artist's Ego could be felt, as Fischer-Lichte pointed out, that it was her, and not some fictional character, that inflicted pain on herself. ${ }^{25}$ However, this was not accompanied by a normal expression of suffering in the performer's works. She did not moan or scream, usually accompanying pain. So it kept the spectators uncertain about how they would behave. In theatre, the effect on the audience would be to amplify the effect of suggested suffering by the actor through various means of expression (e.g. facial expressions, sounds produced). The audience's reaction then becomes compassion, mercy, etc., a kind of psychological participation in the scene. Meanwhile, in the case of Abramović's performance, "all the previously undisputed norms and principles" of both acting and normal life situations associated with the interpretation of expressive symptoms, that "put the audience in a deeply disturbing and agonizing position", were questioned. ${ }^{26}$

It would be hard to say, therefore, that the performance has an introverted and subjective character and that it is focused on the artist's Ego. This example shows that it is not so much a matter of revealing experiences as a game of communication associated with the contact between the subjectivity of the person performing it and the "I" of participants. ${ }^{27}$ The viewers are inclined to participate in different forms of events and, at the same time, in a state of uncertainty, they do not know how to behave, because the existing, learned, socially developed rules turn out to be insufficient or invalid. Fischer-Lichte stresses this fact when she writes that in everyday life there is an immediate intervention rule when someone threatens his or her own life or that of others - even if it involves putting our body and life at risk. Does a similar rule apply to the participation in a performance, however? Abramović poses this dilemma to her audiences. It can therefore be assumed, according to Fischer-Lichte, that not only the

25 E. Fischer-Lichte, The Transformative Power of Performance: A New Aesthetic, S. I. Jain, Routledge, London and New York 2008, p. 12.

26 Ibid.

27 Zbigniew Warpechowski's action, which consisted in piercing his hand with a large nail, was another example of the performance involving self-harm. This action, however, was not only an attempt at self-aggression or to test the limits of resilience to suffering, but was set within the problematic contexts of a moral-political or meta-artistic nature. This was evident during the performance of THE 10 COMANDMENTS (Fifth International Symposium of Performance Art, Lyon 1983), where a long conversation with Professor Stefan Morawski on moral and political issues preceded the piercing of his hand. The reactions of the audience at that time were two-fold - from intellectual to highly emotional. 
performer but also the spectators were put to a test here. The artist tested her resistance to pain, while their participation was based on checking her mental strength, moral sensitivity, etc. She also tested her own pain resistance. The viewers were not the spectators of the unusual spectacle, but its participants, experiencing mental suffering that could be matched by the physical pain that Abramović felt. They were "into a crisis that could not be overcome by referring to conventional behavior patterns" ". 28

Fischer-Lichte devotes a separate chapter of her book to the problem of the audience's participation in the performance. There, she tries to describe the issue by introducing the concept of "feedback loop". This way, it defines the behavior of the audience of theatre performances and performances, which is not limited to the reception of the performance and the safe emotional reaction that is made from a distance. Such reactions may include laughing, beating, sighing, grasping, shaking your legs, turning your back (when the situation is too drastic), rotating on chairs, trying to approach a performer closer to you, and so on. As part of the feedback loop, these activities are perceived by the actors as well as other audiences and may trigger reactions, e.g. other viewers calling to order, quarrels, etc. The result is a feedback network. "In this sense," Fischer-Lichte writes, "performances are generated and determined by a self-referential and ever-changing feedback loop. Hence, performance remains unpredictable and spontaneous to a certain degree". ${ }^{29}$

Does participatory art also include the autopoietic feedback loop? Let us consider three well-known, often commented examples of this type of activity. Since 1990, Argentinian-Thai-American artist Rirkit Tiravanija has been organizing events, during which he serves Chinese soup. In the exhibition room, a bowl hangs above a gas burner, in which water is boiled. Next to it there are cardboard boxes from which the participants can take the powdered soup, pour water over it and eat it. All their activities are voluntary: participants can stay together, or stand or sit on the sidelines. They can talk on any subject. The food offered by Tiravanija is not subject to symbolic interpretation. Claire Bishop writes that it is "a means to allow a convivial relationship between audience and artist to develop". ${ }^{30} \mathrm{He}$ himself is usually present, but does not show anything, does not perform activities that could be the subject of perception and aesthetic experience. The English critic notes that "underlying much of Tiravanija's practice is a desire not just to erode the distinctions between institutional and social space, but between artist and viewer". ${ }^{31}$ Therefore, it is not a matter of continuing activities aimed at entering objects of everyday use and life activities into galleries

\footnotetext{
28 E. Fischer-Lichte, op. cit., p. 13.

29 Ibid, p. 38.

30 C. Bishop, Antagonism ..., op. cit., p. 169.

31 Ibid, p. 169.
} 
or museum halls. What is important to play between people is that they become the most important factors of artistic activity - both creators and audiences.

However, not all of Tiravanija's activities are based on the principle of creating opportunities to meet a group of people directly, to participate, to be together. In 1996, in Kölnischer Kunstverein, he created Untitled (Tomorrow is Another Day), a work that was similar to the installation at first glance. It consisted of a wooden reconstruction of the artist's New York apartment made inside the gallery, which was to be accessible to the public 24 hours a day. Since this reconstruction was equipped with household appliances, visitors could rest in armchairs, cook something in the kitchen, take a shower in the bathroom, and so on. The work itself, carried out in the gallery, did not contain any extraordinary elements imposing very unusual ways of behaving on the recipients. The artist also did not offer any special experiences in connection with finding oneself in this interior. During the stay in it, a feeling of ordinary, everyday life was created. This feeling was reinforced by the contact with other visitors, who behaved more or less similarly in the same place, and by the awareness that at the same time many people are doing the same thing in their own homes. Tiravanija therefore reproduces life situations in which each participant creates their own performance and establishes contacts with other people.

Another variation of participation is in the case of Tatlin's Whisper \#5 by Tania Bruguera, artist of Cuban origin. It took place in the Grand Hall of the Tate Modern in London in 2008. The arriving spectators met two policemen on horses, who were in charge of controlling the movement of the audience. Utilizing the professional experience they acquired during their training, they moved the participants from one side to the other, made them gather in a specific place, etc. These changes were not subject to any practical purpose, but the artistic function was difficult to describe. On the one hand, it was associated with a certain amount of coercion, and on the other, the participation in the project was voluntary. Participants could leave at any time. ${ }^{32}$

This action was announced by the organizers as a performance, and its nature was described as "decontextualization of an action". According to the artist's intention, it was supposed to refer to the issue of the relationship between apathy and anesthetics caused by images in the media. Referring to the scenes of suppression of public demonstrations often shown in newspaper and television pictures, Bruguera wanted to let the participants to feel for themselves what they know from photographs and video footage, as it "may allow them to understand information in a different way and appropriate it because of having lived through it". ${ }^{33}$ Through Tatlin's name, the title referred to the

32 Entry: Artists, op. cit.

33 http://www.taniabruguera.com/cms/478-0-Tatlins+Whisper+5.htm 
Bolshevik Revolution in Russia in 1917, which also appealed to people's hope, whose great expectations are now but a "weak whisper".

The third example is Promien [Radius], action by Paweł Althamer carried out in Minsk, Belarus. Minsk was supposed to become a socialist-realist "City of the Sun". That is why in the film documenting the action the camera focused on various golden items in its field of view. However, the main element of the planned action was the procession of "golden people" (as all participants were wearing golden suits and glasses covering their faces) at sunrise. The march posed a certain risk due to the restrictions on civil liberties in Belarus. Karol Sienkiewicz recounts it as follows: "A procession of several hundred people walks down an empty street, a long, disorderly column that does not know discipline. Three blocks away there is a militia blockade waiting for them. They take off their suits and leave. The first metro trains will take golden, although by no de-goldened people, home". ${ }^{34}$

Althamer used his golden suits in many different actions. However, the example given here is particularly important in terms of the place and context of the action. In this case, the participants' golden suits made political sense. Sienkiewicz writes: "What in a normal country would be an ordinary, cheerful happening, in Belarus develops into an anti-government demonstration. Artur Żmijewski will later write that although the march was interrupted, the goal was achieved: 'The sun has just risen'”. 35

The latter phrase is very important, as it points to the problem of the specific purpose of participatory art. It does not consist in the "operational strategy" that exists in various forms in the case of happenings and performance art. In these types of art, as I have pointed out, there are assumptions that translate into the arrangement or the choice of the place of action, the nature of individual or collective actions, anticipated and unforeseen final effects, etc. The elements of chance, mainly related to the activization of the audience, are not a basic factor, but are always considered as an important possibility. In the case of participatory art, however, the components that are formed in front of and with the involvement of participants lack the operational factor. The place of the action is the gallery rooms, or it is often chosen taking into account various aspects related to the planned action, ${ }^{36}$ but the purpose of what will happen is

34 K. Sienkiewicz, Patriota wszechświata. O Pawle Althamerze, Wydawnictwo Karakter, Muzeum Sztuki Nowoczesnej w Warszawie, Kraków - Warszawa 2017, pp. 333-335.

35 Ibid, p. 335.

36 Some authors who write about participatory art associate it with the concept of site-specific art (cf. e.g. J. Erbel, Marta Żakowska, Sztuka w przestrzeni publicznej, in: Partycypacja. Przewodnik Krytyki Politycznej, eds. J. Erbel, P. Sadura, Wydawnictwo Krytyki Politycznej, Warszawa 2012, p. 254-273). However, as many of this kind of actions take place in ordinary galleries or museum halls, it does not seem justified to emphasize this relationship particularly strongly. 
not. If the participants can feel it (as was the case during Althamer's action in Minsk), it does not translate into a specific action program. It is known that being in a certain place and doing certain things by certain people will bring results, but most often we do not know exactly what it will be like. Participatory art cannot therefore be judged on its effectiveness. It can even be said that this criterion, so important in social and political life, is being problematized here.

This problem was brought to the attention of Dorota Michalska, who distinguished Althamer's work from Polish critical art. Regarding Promień, she wrote that there were no specific postulates, because "Althamer did not formulate the precise goal of the march, i.e. the real stake of the participation" ${ }^{37}$ Therefore, there were many participants but they were not brought there because of a specific slogan. Michalska also recount Joanna Bednarek's view that in this case, as well as in other situations arising within the framework of participatory art, action goes "beyond the politics of identity, and thus also beyond the logic of purpose. The lack of an essentialist understanding of identity translates into a lack of specific slogans". 38

And in the case of performance art, did the empowerment associated with the role of the performing artist also affect the participants? Fischer-Lichte believes that this was the way it was supposed to be, both in terms of how it felt and the activities carried out by the audience. Summarizing her reflections on the activation of viewers following the performance, Abramovic writes in Innsbruck: "In all events, the spectators here were admitted not merely as feeling and thinking but also as acting subjects - as actors." ${ }^{39}$ One can say that the performance is supposed to transform a group of individual identities into a community capable of taking collective action. It is not a group formed by the adoption of specific slogans, but it is formed as a reflex. Fisher-Lichte wrote: "The communities brought forth by these collective actions constituted a temporary social reality. They disappeared as soon as the actions were performed. The conditions for success did not depend on sustained deliberations and convictions that had to be shared by all members of the community. They merely required members of two otherwise clearly distinct groups - actors and spectators - to engage in common activities for the duration of the performance". ${ }^{40}$ In the case of participatory art, similar activities are also performed by human beings. Tiravanija probably also ate Chinese soup with the participants of $U n$ -

37 D. Michalska, Etos partycypacji. Pawet Althamer i prawo Innego, malakulturawspolczesna. org/2014/02/27/dorota-michalska-etos-partycypacji-pawel-althamer-i-prawo-innego/ (accessed 3 June 2018).

38 Ibid

39 E. Fischer-Lichte, op. cit., p. 18.

40 Ibid, p. 55. 
titled (Free). Bruguera may have been in a group of people controled by police officers. Althamer marched in a golden suit together with other participants of the action Promien in Minsk. However, were all the participants were merged into one, or were they were acting side by side and communicating as single unities? Certainly, there was no feedback loop constitutive for performance, which could be created when the performer and the audience are separated at the starting point, and then a community is formed through observation of his actions. In the case of participatory art, there is hope for the spontaneous formation of a community in which the artist will be one of the participants. ${ }^{41}$

\section{BIBLIOGRAPHY}

Bishop Claire (2006) Participation. Documents of Contemporary Art, London - Cambridge, Mass.: Whitechapel and The MIT Press.

Bishop Claire (2012) Antagonism and Relational Aesthetics, [in:] Theory in Contemporary Art since 1985, ed. Z. Kocur i Simon Leung, Malden-Oxford-Chichester: Wiley-Blackwell.

Bishop Claire (2012) Artificial Hells Participatory Art and the Politics of Spectatorship, London, Ney York: Verso.

Bourriaud Nicolas (2001) Public Relations. Interview with Bennett Simpson, “Artforum”, April, http://web.mit.edu/allanmc/www/simpson1.pdf

Bourriaud Nicolas (2002) Relational Aesthetics, transl. Simon Pleasance and Fronza Woods with M. Copeland, Dijon: Les presses du réel.

Debord Guy (1994) The Society of the Spectacle, transl. D. Nicholson-Smith, New York: Zone Books.

Dempsey Amy (2002) An Encyclopaedic Guide to Modern Art. Styles, Schools and Movements, London: Thames \&Hudson.

Encyclopdia of Aesthetics (2014) Kelly Michael Editor-in-Chief, Oxford University Press, (http:// arts.berkeley.edu/wp-content/uploads/2015/03/Participatory_Art-Finkelpearl-Encyclopedia_ Aesthetics.pdf)

41 In order to avoid misunderstanding, I would like to strongly emphasize that I do not question the political aspects of participatory art. This applies to all the participation concepts to which I have referred. During the interview with Bennetta Simpson, Bourriaud said: "What for? What does the new kind of contact produce? If you forget the 'what for' I'm afraid you are left with simple [...] producing interpersonal relations for their own sake and never addressing their political aspects." (N. Bourriaud, Public Relations. Interview with Bennett Simpson, "Artforum" April 2001, http://web.mit.edu/allanmc/www/simpson1.pdf. Instead, I would like to draw attention to the specificity of setting these objectives and communicating them. 
Erbel Joanna, Żakowska Marta (2012) Sztuka w przestrzeni publicznej, [in:] Partycypacja. Przewodnik Krytyki Politycznej, ed., J. Erbel, P. Sadura, Warszawa: Wydawnictwo Krytyki Politycznej, p. 254-273).

Fischer-Lichte Erika (2008) The Transformative Power of Performance: A New Aesthetic, S. I. Jain, London and New York: Routledge.

Kester Grant H. (2004) Converation Pieces: Community and Communication in Modern Art, Berkeley: University of Kalifornia Press.

Lebel Jean-Jacques (1965) A Point of View on Happenings from Paris, September: Paris

Lebel Jean-Jacques (1988) Retour d'exil. Peintures, dessins, collages 1954-1988 exposition catalogue Galerie 1900-2000, Paris.

Michalska Dorota, Etos partycypacji. Pawet Althamer i prawo Innego, malakulturawspolczesna. org/2014/02/27/dorota-michalska-etos-partycypacji-pawel-althamer-i-prawo-innego/ (3 June 2018).

Pawłowski Tadeusz (1984) Introvert-Subjectivist Performance Versus Extrovert-Objectivist Happening, in: 1979-1983. Five Years Performance-Art in Lyon, [in:] Comportement Environment Performance, ed. H. Besacier, M. Verdier Lyon.

Pawłowski Tadeusz (1988) Happening, Warszawa: Wydawnictwa Artystyczne i Filmowe.

Pelzer Gerrit (1984) Questions Relating to Performance, in: 1979-1983. Five Years Performance-Art in Lyon, [in:] Comportement Environment Performance, ed. H. Besacier, M. Verdier, Lyon.

Sienkiewicz Karol (2017) Patriota wszechświata. O Pawle Althamerze, Wydawnictwo Karakter, Kraków - Warszawa: Muzeum Sztuki Nowoczesnej w Warszawie.

www.taniabraguera.com/cms/478-0-Tatlins+Whisper+5.htm

\section{PERFORMANS A SZTUKA PARTYCYPACYJNA (streszczenie)}

Związki sztuki partycypacyjnej z performansem są złożone. Z jednej strony dostrzegane jest ich powinowactwo, gdyż w jednym i drugim przypadku mamy do czynienia z podkreśleniem roli działania, $\mathrm{z}$ drugiej jednak strony akcyjność ta jest inaczej pojmowana. Wzięcie pod uwagę pierwszego aspektu powoduje, że w informacjach prasowych muzealnych lub galeryjnych przejawy sztuki partycypacyjnej określane są jako "performansy" - czasami z dodaniem jakiegoś przymiotnika. Celem artykułu jest nieco dokładniejsze przyjrzenie się temu zagadnieniu.

Rozważania rozpoczyna zwrócenie uwagi na fakt, że jako punkt odniesienia dla sztuki partycypacjnej częściej bierze się pod uwagę happeningi (zwłaszcza europejskie) z lat sześćdziesiątych, niż sztukę performans. Jako powód Claire Bishop wskazuje występującą w happeningach świadomą społeczno-polityczną krytykę społeczeństwa konsumpcyjnego. Autorka artykułu dowodzi, że argumentem może być także struktura tych działań. Omawiając zasady udziału publiczności w happeningach i sztuce performance odwołuje się do poglądów Eriki Fischer-Lichte zakładają- 
cej powstawanie w drugim przypadku "pętli feedbacku" łączącej performera i widzów. Pętla taka nie powstaje w przypadku happeningów i nie może ukształtować się w sztuce partycypacyjnej, gdzie artysta jest tylko jedną z osób uczestniczących w działaniu. W artykule rozważone zostają przykłady charakterystycznych dzieł opartych na zasadzie partycypacji: Rirkita Tiravaniji, Tanii Bruguery i Pawła Althamera. W żadnym z nich artysta nie zajmował wyróżnionej pozycji, nie wpływał na sposoby zachowania się uczestników, a stwarzał tylko szansę powstania wspólnoty. W pierwszym przypadku jej kształtowanie się było całkowicie swobodne, w drugim pojawiały się formy presji, nacisku i uwalniania od niego, w trzecim występowała zachęta. Nigdzie jednak artysta nie określał zasad działania, nie podawał stawki, nie wyznaczał celów. Jednocześnie zaś, przy uczynieniu uczestników twórcami przebiegu akcji, w sztuce partycypacyjnej istotne pozostaje pytanie "po co?", które nadaje jej charakter polityczny.

Słowa kluczowe: sztuka partycypacyjna, happening, performance art, Nicolas Bourriaud, Claire Bishop, Erika Fisher-Lichte 